\title{
Farmers Knowledge Level of Potato Crop Cultivation in Rabia Sub- district / Nineveh Governorate
}

\author{
A. Z. Y. Alhafidh
}

Dept.of agricultural Extension and Technology -College of Agric. and Forestry /

Univ- of Mosul

Email: asmaa_alhafidh@yahoo.com

\begin{abstract}
The research aims to identify level of farmers knowledge in Rabia Subdistrict/Nineveh governorateon potato cultivation, identifiy the differences in Knowledge level according to some variables: Age, Education level, years' number of experience potato farming, land ownership, number of dependent information sources of potato, monthly income, type farming career and previous training, and identify the problems facing the potato cultivation. The data were collected by a questionnaire, and analyzed by using Kruskal-Wallis test, Mann_Whitney test. The important results showed that $(45.88 \%)$ of the farmers have medium knowledge, the higher knowledge level in crop service field, there are significant differences in knowledge levels according to age, educational level, number of experience years of potato crop, type of farming career and the important problems facing potato farmers is high price of production cost, also there are some recommendations and suggestions.
\end{abstract}

Keyword: Knowledge level, potato farmers, problem.

\section{Received: 11/10/ 2018, Accepted: 19/3/2019 \\ Introduction}

Rural community development programs have a great interest to governmental institutions ,especially in developing countries this is due to the believe of these countries including Iraq that the attitude towards the agricultural development is the foundation of the development as a essential step to development society as a whole (Al-Eqabi and Al-Badri,2007). Agricultural area development is complicated process , which involves many things and troubles which require a solutions (Ziemianczyk etat,2014 ), to face these troubles must the techniques be translated in the confirmation stage, farmers seeks reinforcement innovation -decision and may reverse this decision if exposed to conflicting messages about the innovation ,also to avoid a state dissonance or reduce it and to overcome these problems(Rogers,2003) .The lack of knowledge and its provision on technological is an issue as farmers are unable in obtaining the required knowledge and skills, extension services are critical to increase agriculture production(Anonymous,2009), potato is grown with spring and autumn berries for the consumtion or seed production demand has increasedon it and the Iraqi consumption pattern has increased significantly (Thallaj and AlNajjar,2013)Therefore, it is necessary to investigate the levels of potato farmers in the under study area prior to the transfer technology that specific to potato cultivation, in order to identify the flaw in their knowledge and the associated struggles and spread the realist techniques needed by the potato farmers to develop the crop and increase production (quantity and quality), despite the tremendous development on the level of researches and scientific achievements, our knowledge of the essence of information, 
functions, characteristics and their role in nature and society, the technologies still seemed to be modest concerning to potato cultivation and there are many issues remained in need of further development and deeper examination (ShamsAldin,2011) According to research that conducted by the Al-jarjry(2011), results showed that effectiveness is the greatest persentage (96\%) of farmers were have benefited from the project, with regard to the important role of the potato farmers and to prepare them properly to be able to cover all the business of cultivation and production efficiently to get greatest advantage, especially the potato crop farmers in Rabia which are very limited due to high agricultural costs and the farmers of potato cultivation so-called (trade farmers) ${ }^{1}$. Given the lack of previous studies directly relevant to the topic, which were focused on the following studies: revealed Al-Talib(2007) in his study that $8.75 \%$ of farmers had low knowledge level , $51.25 \%$ had medium ,40\% high level of knowledge in tomato growing. There knowledge in tomato growing, also Mahmoud(2008) in his study found there were a reversible significant correlation between extension needs and the following variables: academic achievement, the number of agriculture working years, the level extension communication with information sources and a weak inverse correlation with the farming methodology, land area, and no significant correlation with age and productivity and types of agriculture. So the study of Al-Abbassi etat(2010) found that knowledge level of rural youth in the summer vegetables was low and there were no significant differences in the level of their knowledge according to the following variables: age, education level, types of profession, the number of working years in agriculture, agricultural land area, the degree of information sources .So Al-khazraji(2011) showed in his study a need to design a knowledge plan for those extensions planners ranging between (6-135) degree, $46 \%$ of them have a need between (91-135) degree and is located within the range of large needs ( means so limited knowledge). There are some questionsins in this research are :

1.What is the knowledge level of farmers in Sub-district in the cultivation of the potato crop in general?

2. What is the degree of knowledge levels of potato farmers in each knowledge field and in each knowledge statement?

3.What are the differences in the knowledge levels according to some variables?

4. What are the problems that facing potato farmers in Rabia sub-district?

The objectives of current research are as follows:

1. To determine the knowledge level of farmers in Sub-district in the cultivation of the potato crop in all fields which are: variety selection, crop cultivation, crop service (fertilization, pest control, hoeing), crop irrigation and crop harvesting.

2. To identify the degree of knowledge levels of potato farmers in each knowledge field and in each knowledge statement.

3. To identify the differences in the knowledge levels according to the following variables: age, educational level, number of experience years of potato farming, land ownership, the number of dependent information sources, monthly income and previous training.

4. To Identify the problems that facing potato farmers in Rabia sub-district.

1 Rabia agriculture directorate, monitoring Department . 


\section{Material and Methodologies}

The study population consists of all of the farmers of Rabia Sub-district in Nineveh Governorate. Iraq Consists of 18 Governorate ,Formal Governorates divided to Districts ,there is 188 District in Iraq, which divided to Sub-districts ,Iraq has 393 Sub-districts (Shafeeq,2016). The majority of farmers in the research area are potato farmers,this Sub-distruct consists of (80) villages. Some of these villages are: Abu Hujera, Ewaynat, Tel-al-Hawa, tel-Hyaa, Tal atlas, Mwshat, Almahmodya,Alsaudia, Alqahera, Krhdw, Alabtakh, Kardahir, Musherfa, Al-Elqana, Tal Elwardian, AlAlqanah, Tal Wardan, Al-Moumi, Bir Okla, Abu Khashab, Mashreq, Jalabat and Rajam Hassan. The research consists of all the potato crop farmers of Sub-district in Ninevah Governorate, which are (85) farmers, a questionnaire is prepared for the purpose of data collection and research, consisted from three parts. The first part consisted of personal and economic and communication variables, were measured as follow: Educational level that has been identified by giving the farmers one educational degree for each educational level as the following: 1-Elementary 2Medium, 3- High School, but the number of experience years of potato farming was measured by giving a number of years of experience in crop planting. The land ownership is measured by giving the number 1 for the land ownership, number 2 for the employee in the ground, and number 3 for contracting. The number of approved of dependent potato information sources used in the cultivation of potato crop were measured by the number of dependable sources, the monthly income: measured by given a zero to the farmers without income and 1 to those with low incomes, and 2 to the farmers who gain average income and 3 to those with good income. While the type of farming career the main occupation giving 1, and secondary agriculture career giving 2 .Finally variable previous agricultural training measured by giving 1 to the previous trained farmer and 2 to the not previous trained farmer, but this variable have been deleted from the study variables, due to the fact that all the farmers didn't join any training course in potato cultivation. The second part of the questionnaire is test of the knowledge level of the potato farmers, which covered five fields of knowledge :variety selection 4 statements, crop cultivation 4 statements, a crop service (fertilizing, pest control, hoeing) 10 statements, irrigation 5 statements, crop harvest 5 statements, the total number of these statements in test were primarily 28 statements. The content validity was tested by submitting the questionnaire to a number of experts of the department of horticulture / College of agriculture and forestry/ Mosul University, in addition to that, extreme comparisons was used the value of the calculated $\mathrm{T}$ is (12.3) degree, which is the larger than tabular $\mathrm{T}$ value at $1 \%$ significance level, indicating that the test has the ability to discriminate between both groups high and low knowledge level (Abdalhafidh and Bahi,2000) by applying the test on a random sample of 30 potato farmers from Alshrikhan village during March 2016 (was excluded from the final sample) Then a reliability tested by applying Kuder-Richardson equation ,the value of reliability coefficient (0.89) which demonstrated a high reliability of the test. It was found the discriminatory power of the instrument as amended statements that ranged from $(0.2-0.29)$,so it has been found the coefficient of difficulty; it was deleted statements outside the range $(0.20-$ 0.80 ) thus numbered statements at the final test about 25 statements of the following types: multiple choice statements; there is three alternatives to answer one of them 
chosen by the respondent, also statements of true or false and completion statements the respondent complete the lack, supplemented to the information.

The third part of the questionnaire included 21 problems met triple criterion (always, sometimes, rarely) has given him the following weights $(3,2,1)$ respectively, following the completion of the form. The research data was collected by personal interview, and analyzed by using the percentage ,standard deviation, arithmetic mean and median, Mann Whitney for variables which divided into two categories ,KruskalWallis for variables which were divided into three categories and more (Tharwat,2004 )that is because the data are not normally distributed. The knowledge levels were determined by summating the degrees of all knowledge fields for research; as well as knowledge level for each field and each knowledge statement , the research conducted during the period(January 2016 and continued till August 2018 ).

\section{Result and discussion}

First: Determination the knowledge level of farmers in the cultivation of the potato crop to all fields in general : Can be seen from the table (1) that (45.88)\% of the farmers have intermediate knowledge level, whereas those with low knowledge level (40)\%, the percentage of people with higher knowledge levels (14.12) \% of total potato farmersin the study area.

Table(1): Distribution of farmers according to knowledge level in potato cultivation

\begin{tabular}{|c|c|c|}
\hline Categories & The number & $\%$ \\
\hline Low (8-11) degrees & 34 & $40 \%$ \\
\hline Medium (12-15) degrees & 39 & $45.88 \%$ \\
\hline High (16-19) degrees & 12 & $14.12 \%$ \\
\hline The total & 85 & $100 \%$ \\
\hline
\end{tabular}

lesser value $=8$, highest value $=19$, arithmetic mean $=12.78$, standard deviation $=$ 2.68

As illustrated in table (1) the knowledge level of the farmers is medium in the first , low in the second, high in the third class, that because farmers in the area need to participation training courses to Strengthening their information and support their education and awareness constantly and developing day after day. this result consistents by Alkhazraji (2011),Al-Abassi etat(2010) and different from Aljarjry (2011), Altalib ( 2007) .

Second: Determining the degree of knowledge levels in each knowledge area and in each statement as shown in the table (2): 
Table (2): The order of the field and statements according to the Weighted and arithmetic mean of knowledge level of farmers.

\begin{tabular}{|c|c|c|c|}
\hline Fields and statements & $\begin{array}{l}\text { Arithmetic } \\
\text { mean }\end{array}$ & $\begin{array}{c}\text { Weighted } \\
\text { Mean }\end{array}$ & Rank \\
\hline $\begin{array}{c}\text { Crop service (Fertilization , pest control, } \\
\text { hoeing) }\end{array}$ & & 0.569 & 1 \\
\hline The best way to pest worms on potato. & 0.95 & & 1 \\
\hline $\begin{array}{l}\text { The proper procedure for the prevention of } \\
\text { early cultivator disease }\end{array}$ & 0.83 & & 2 \\
\hline $\begin{array}{l}\text { Know the number of hoeing times during the } \\
\text { crop service }\end{array}$ & 0.81 & & 3 \\
\hline know the exact times to stop hoeing & 0.57 & & 4 \\
\hline The ideal date to add animal manure crop & 0.45 & & 5 \\
\hline The ideal date to add the chemical fertilizer & 0.42 & & 6 \\
\hline $\begin{array}{l}\text { The appropriate conditions to add to the Soil } \\
\text { phosphorus }\end{array}$ & 0.32 & & 7 \\
\hline The proper amount of manure fertilizer added & 0.21 & & 8 \\
\hline Crop cultivation & & 0.557 & 2 \\
\hline The preferred method for potato cultivation & 0.87 & & 1 \\
\hline The Appropriate soil moisture & 0.84 & & 2 \\
\hline $\begin{array}{l}\text { Know effect the addition of animal manure } \\
\text { on the potato }\end{array}$ & 0.72 & & 3 \\
\hline $\begin{array}{l}\text { The best way to hoe herbs in the sweet potato } \\
\text { Fields }\end{array}$ & 0.24 & & 4 \\
\hline $\begin{array}{l}\text { Comparison between the right depth of } \\
\text { cultivation of autumn and spring potato }\end{array}$ & 0.23 & & 5 \\
\hline Irrigation & & 0.523 & 3 \\
\hline $\begin{array}{l}\text { know the number of irrigation times of } \\
\text { soil during the farming }\end{array}$ & 0.83 & & 1 \\
\hline $\begin{array}{l}\text { Find out the damage caused by the dumping } \\
\text { of soil-water }\end{array}$ & 0.81 & & 2 \\
\hline The best way to irrigate the sweet potato crop & 0.27 & & 3 \\
\hline The amount of water suitable for irrigation & 0.18 & & 4 \\
\hline Selection of Potato variety & & 0.44 & 4 \\
\hline The perfect time for planting Are & 0.62 & & 1 \\
\hline $\begin{array}{l}\text { The appropriate time to harvest alpha variety } \\
\text { compared with Are variety }\end{array}$ & 0.5 & & 2 \\
\hline The advantages of Benji variety & 0.48 & & 3 \\
\hline The advantages of the Ari Variety & 0.14 & & 4 \\
\hline The Harvest & & 0.394 & 5 \\
\hline $\begin{array}{l}\text { The proper time for potato seeds regarding } \\
\text { maturity }\end{array}$ & 0.55 & & 1 \\
\hline $\begin{array}{l}\text { The appropriate month to harvest spring } \\
\text { potato }\end{array}$ & 0.44 & & 2 \\
\hline $\begin{array}{l}\text { The indications and outstanding relations on } \\
\text { the, leaves, seedlings and securities }\end{array}$ & 0.31 & & 3 \\
\hline $\begin{array}{l}\text { The appropriate month to harvest autumn } \\
\text { potato }\end{array}$ & 0.20 & & 4 \\
\hline
\end{tabular}


that is at a higher knowledge level of farmers the crop service field which indicates that farmers have good knowledge in that field.

Third: Identifying differences in the level of knowledge for farmers according to some variables:

1. Age: the results from the table (3) showed that the highest age is 56 years and less age is 25 years with a mean 41.63 and a standard deviation 9.32 when the distribution of farmers according to the age groups, it shows that the high proportion of abig age category ( 45 and above) is $43.52 \%$ and represented age group (35-44) years of $42.35 \%$ while the small proportion of the age group (34 years and less) $14.11 \%$, to determine differences in knowledge level of potato farmers according to the farmers' age, the Kruskal-Wallis test(Al-Abbasi,2015) was used and the value of calculated $\mathrm{H}$ is 12.30 which is more than the tabular value at a significant level 5\% which mean that there are significant differences in the knowledge level according to farmers' age ; this result consistents with the findings of Altalib (2007), differs with the findings of each of the Mahmoud ( 2008 ) Alabasi etat ( 2010 ).

2. The education level: The distribution of farmers according to categories of educational level shows a high rate percentage as education level of the primary level accounted for about $52.29 \%$, followed by a group of illiterates, amounting to $0.35 \%$, followed by the ratio of the two intermediate and secondary school $0.04 \%$, has revealed that significant differences were found in knowledge level, according to educational levels, since the value was calculated Kruskal-Wallis Test (10.06), This value was significant at $1 \%$ level. This is because the educated farmers have obtained sufficient information; make them aware and different from their peers. This result consistents with the conclusion of Mahmoud( 2008)and varies with the Al-Talib ( 2007 ), Al Abasi etat( 2010 ).

3. The number of experience years of potato farming: It appeared to be less number of farmers respondent of potato (1) years and the highest number (27) years. With (6.68) mean and (11.8) standard deviation, and distribution of farmers according to years of potato farming and shows a high proportion of the middle class (10-18) years, reach to $56.47 \%$, followed by the class number of a few (1-9) years $(29.41 \%)$ of the total then a category of (19-27) years old , $9.41 \%$ of the total of farmers included in the study.It reveals significant differences in knowledge level to grow potatoes farming varies according to the number of years since the value of $\mathrm{H}$ Kruskal-Wallis Test 4.98, values was significant at 5\% level, which indicates that the more years potato farming and farm the more the accumulated experience and knowledge, he learns a lot of things over the years, This result consistents with , (Al-Abbassi etat ( 2010 ), and varies with Al Talib (2007).

4. Ownership of the land: Farmers' distribution according to the ownership of land, found that $54.11 \%$ of farmers were among the ownerships, though $41.17 \%$ of them are employees in agricultural land. $4.70 \%$ in the category of contractors on agricultural land, the result showed no significant differences in knowledge level varies according to the property of the land using Kruskal-Wallis ; the calculated value was a significant level at $5 \%$ this means that any farmers, ownerships of the land, or employees working in agricultural land or contractors with some knowledge 
in either did not change in the level of knowledge, this result consistents with the study of Al Talib ( 2007 ).

5. A number of dependent information sources: it appeared to be the highest numerical value information sources (6) and lower numerical value of information sources (1), with a mean of source the (2.29) and standard deviation of 1.34. Distribution of farmers according to categories of information sources between the percentage of farmers who had many sources of category (3 and above) was $40 \%$, followed by a few numbered sources ( 1 source), then the medium source (2). The results showed no significant differences in the knowledge level of farmers depending on the number of information sources used in the cultivation of potato using the Kruskal Wallis test. The value of calculated $\mathrm{H}$ is 1.77 at the level of 5\%, and this result consistents with the conclusion of Mahmoud ( 2008 ), and consistents with the conclusion of Al-Abbassi etat(2010) and varies with Al Talib (2007) .

6. The monthly income: It appeared to be the highest numerical value of monthly income of farmers identified the numeric value 3 and lower monthly income is no numeric value. It was found that the highest proportion among monthly income $60 \%$, followed by a weak class with average monthly income of $21.17 \%$ and then rated with a good monthly income of partial $14.11 \%$ while Group $4.7 \%$ with zero income. It founds there are differences in the knowledge level of potato farmers according to their monthly income, amounting to $\mathrm{H}$ value for Kruskal Wallis test is not significant at 4.08 significant level $5 \%$.

7. Type of farming career: Distribution of farmers by the type of farming career shows that $78.82 \%$ of farmers were among the farmers who engaged with agriculture as their main vocation. And $21.17 \%$ were among the group whose engaged with agriculture as a secondary vocation, Results showed significant differences in the knowledge level of farmers according to the type of the farming career by using test of Mann_Whitney test (2) used if the variable was divided into two categories: (0.07) $\mathrm{Z}$ value calculated is less than the tabular value of the $\mathrm{Z}$ spreadsheet at a significance level of $1 \%$. This shows that sort of career of agriculture if key for farmers, making farmers dedicated to agriculture and increasing the knowledge in this field compared with farmers who engaged in agriculture as a secondary vocation. This result differs with what reached Al-Abbasi etat (2010) differences in knowledge level according to this variable.

As can be seen from table 4 that the problems ranked first is the problem of high production costs (fuels, fertilizers, seeds), with a mean of 2.87 due to lack of governmental support, the suspend of fertilizer processing statements manufactures for free or supported.

Also, the spray of insects, with a mean of 2.71this problem is a very big because of the significant problems which threat the potato insects, especially Colorado beetle insect that acquired immunity against all kinds of pesticides that used in Rabia Subdistrict , also the problem of the lack of marketing outlets, with a mean of 2.62 as it can be difficult for farmers market silo potato to wait for 30-45 days to unload the crop. 
Mesopotamia J. of Agric.

Vol. (47) No. (1) 2019
ISSN: 2224 - 9796 (Online)

ISSN: 1815 - $316 \mathrm{X}$ (Print)

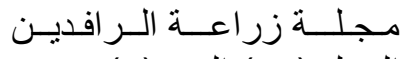

المجلد (47) العدد (1) 2019

Table (3): The difference in the level of knowledge according to some variables

\begin{tabular}{|c|c|c|c|c|c|c|c|}
\hline Variables & Frequency & Percent & Median & $\begin{array}{l}\text { The average } \\
\text { rank }\end{array}$ & H value & $\begin{array}{c}\mathrm{Z} \\
\text { value }\end{array}$ & $\begin{array}{c}\mathrm{P} \\
\text { Value } \\
\text { for } \\
\text { significant }\end{array}$ \\
\hline \multicolumn{7}{|c|}{ Age } & \\
\hline $\begin{array}{l}\text { Small (34 and } \\
\text { younger) }\end{array}$ & 12 & $14.11 \%$ & 2 & & & & \\
\hline $\begin{array}{l}\text { Medium }(35- \\
44)\end{array}$ & 36 & $42.35 \%$ & 2 & & $12.30^{*}$ & & 0.002 \\
\hline $\begin{array}{c}\text { Large ( } 45 \text { and } \\
\text { over) }\end{array}$ & 37 & $43.52 \%$ & 1 & & & & \\
\hline \multicolumn{7}{|c|}{ The level of Education : } & \\
\hline Illustrate & 30 & $35.80 \%$ & 2 & 50 & & & \\
\hline $\begin{array}{c}\text { Primary } \\
\text { schools (2) } 47\end{array}$ & 47 & $52.94 \%$ & 2 & 47.7 & & & \\
\hline $\begin{array}{l}\text { Intermediate } \\
\text { (3) } 4\end{array}$ & 4 & $4.705 \%$ & 1 & 47.5 & $7.69^{*}$ & & 0.05 \\
\hline $\begin{array}{l}\text { High schools } \\
\text { (4) } 4\end{array}$ & 4 & $4.705 \%$ & 9 & 54 & & & \\
\hline \multicolumn{8}{|c|}{ The number of the experience years of potato farming : } \\
\hline $\begin{array}{c}\text { Few (1-9) } \\
\text { years }\end{array}$ & 25 & $\begin{array}{c}29.41 \\
\%\end{array}$ & 2 & 46.4 & & & \\
\hline $\begin{array}{c}\text { Medium (10- } \\
18) \text { years }\end{array}$ & 48 & $\begin{array}{c}56.47 \\
\%\end{array}$ & 2 & 44.6 & $* 4.98$ & & 0.053 \\
\hline $\begin{array}{c}\text { Large (19-27 } \\
\text { years) }\end{array}$ & 8 & $9.41 \%$ & 1 & 29.7 & & & \\
\hline \multicolumn{8}{|c|}{ Land ownership: } \\
\hline $\begin{array}{l}\text { The ownership } \\
\text { of the land }\end{array}$ & 46 & $54.11 \%$ & 2 & 44.9 & & & \\
\hline employees & 35 & $41.7 \%$ & 2 & 39.2 & 2.29 & & N.S 0.318 \\
\hline Contracted & 4 & $4.70 \%$ & 2 & 54.0 & & & \\
\hline \multicolumn{8}{|c|}{ No. of sources information } \\
\hline (1) Source & 28 & $31.76 \%$ & 2 & 47.2 & & & \\
\hline (2) sources & 26 & $26.13 \%$ & 2 & 49.8 & 1.77 & & $\begin{array}{ll}\text { N.S } & 0.412 \\
\end{array}$ \\
\hline $\begin{array}{l}\text { (3) Sources } \\
\text { and more }\end{array}$ & 31 & $40 \%$ & 1 & 39.4 & & & \\
\hline \multicolumn{8}{|c|}{ Monthly income : } \\
\hline $\begin{array}{l}\text { There is no } \\
\text { income }(0)\end{array}$ & 4 & $4.70 \%$ & 2 & 54.0 & & & \\
\hline (1) weak & 51 & $60 \%$ & 2 & 43.8 & 4.08 & & \\
\hline Average (2) & 18 & $21.17 \%$ & 1 & 34.7 & & 0.253 & N.S \\
\hline Good (3) & 12 & $14.37 \%$ & 2 & 45.2 & & & \\
\hline \multicolumn{8}{|c|}{ The type of farming career: } \\
\hline The main 1 & 69 & $81.17 \%$ & 2 & 39.6 & & $\begin{array}{c}0.07 * \\
*\end{array}$ & 0.0012 \\
\hline Secondary 2 & 16 & $18.28 \%$ & 2 & 57.6 & & & \\
\hline
\end{tabular}

(*)Refers to the significant value at the level of $5 \%(* *)$ refers to the significant value at the level of $1 \%$

Fourth: Identifying the problems facing potato crop farmers: Calculating Arithmetic mean of the problems and was arranged as illustrated in table (4) 
Table (4): The order of the problems facing the potato farmers

\begin{tabular}{|c|c|c|}
\hline The Problems & $\begin{array}{l}\text { Arithmetic } \\
\text { mean }\end{array}$ & $\begin{array}{l}\text { Rank } \\
\text { order }\end{array}$ \\
\hline $\begin{array}{l}\text { High prices of production costs (fuel, seeds, } \\
\text { fertilizers) }\end{array}$ & 2.87 & 1 \\
\hline The spread of Colorado beetle insect & 2.71 & 2 \\
\hline The lack of adequate marketing outlets & 2.62 & 3 \\
\hline Dumping markets consuming imported potato & 2.50 & 4 \\
\hline Lack of mechanical harvesting machines & 2.47 & 5 \\
\hline Import of not bad varietyes & 2.45 & 6 \\
\hline $\begin{array}{l}\text { The complexity of the procedures for obtaining } \\
\text { seeds. }\end{array}$ & 2.43 & 7.5 \\
\hline The High mobilization costs & 2.43 & 7.5 \\
\hline $\begin{array}{l}\text { Receive the farmers from the banks damaged and } \\
\text { very small cash money }\end{array}$ & 2.41 & 9 \\
\hline $\begin{array}{l}\text { There aren't useing guided bulletins for farmers } \\
\text { potato }\end{array}$ & 2.30 & 10 \\
\hline High transport costs & 2.25 & 11 \\
\hline $\begin{array}{l}\text { The lack of training opportunities for farmers in the } \\
\text { cultivation of potatoes }\end{array}$ & 2.20 & 12 \\
\hline The lack of suitable premises for storing the crop & 2.18 & 13 \\
\hline The lack of pesticides sick & 2.16 & 14.5 \\
\hline The shortage of irrigation water & 2.16 & 14.5 \\
\hline The high costs of harvest & 2.09 & 16 \\
\hline $\begin{array}{c}\text { The delays in providing seeds in both spring and } \\
\text { autumn cultivation }\end{array}$ & 9.07 & 17 \\
\hline Lack of fertilizers & 1.97 & 18 \\
\hline Lack of employment and to harvest & 1.95 & 19 \\
\hline $\begin{array}{l}\text { The repetition of agriculture land infected with } \\
\text { diseases }\end{array}$ & 1.84 & 20 \\
\hline $\begin{array}{l}\text { The lack of experience in the diagnosis of diseases } \\
\text { and pests }\end{array}$ & 1.83 & 21 \\
\hline
\end{tabular}

Conclusions:Based on the results of research, the main conclusions were:

1. The majority of farmers of the potato crop in Rabia Sub-district have medium knownledge tends to decline in the cultivation of the potato crop, because the lack of awareness and their education, and their support by the additive, it is agricultural cooperatives and their growing course lay on topics of potato cultivation. 
2. Potato farmers lack agricultural knowledge service crop particularly in comparison with other areas of fertilization and pest control and disease with hoeing jungle, which required high knowledge and experience in the cultivation of potatoes.

3 . The education of farmers and increase the number of years of work experience in cultivating vegetables and focus on farmers who are taking agriculture main profession, considerd These important reasons to increase the knowledge of potato farmers in the cultivation of research area.

4. The personal variables: ownershipof the land, the number of information sources, and the monthly income play a weak role in the provision of agricultural information of potato farmers in the area.

5. The problem of the high cost of production has ranked first among other problems; this is because the government support is discontinued and fertilizerprocessing supplies manufacture in the area free.

In the light of the above conclusions, we recommend the following:

1. Preparing training courses in coordination with agriculture college in Mosul, an intense potato farmers strategic importance of this crop.

2. Activate the agricultural information Agricultural Radio and television programmers and to confirm this crop and the strategic importance of its development.

3. Provide environmental information sources by T.V. programes in cultivating vegetables and especially to farmers in Rabia with a good level of education.

4. The need to continue to expand the potato farmers of agricultural support project by the Ministry of agriculture, and implemented by the center, in cooperation with the Directorate of agriculture at extension of Nineveh to the largest number of farmers in the province.
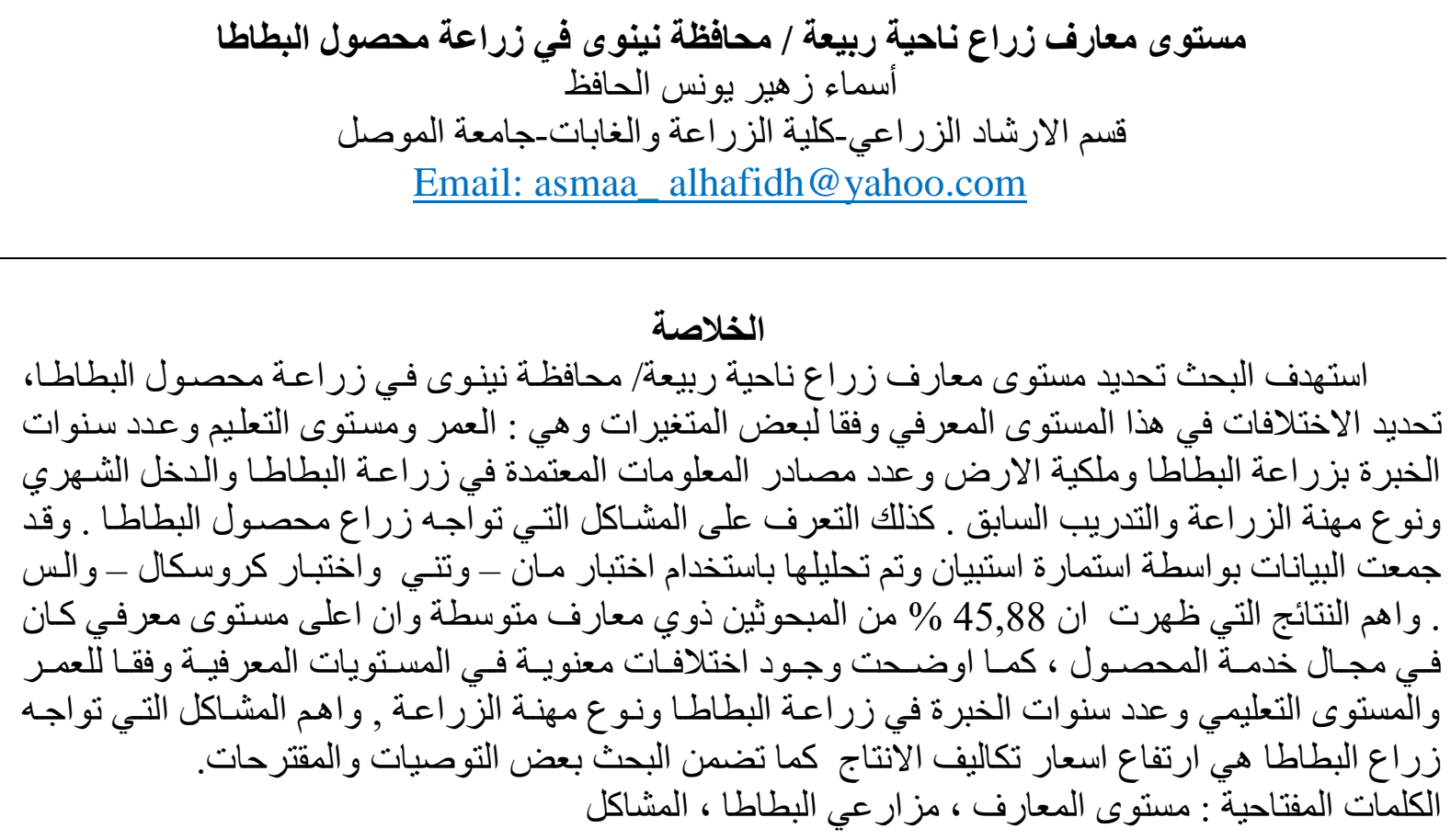


\section{REFERENCES}

Abdul Hafiz, E. M. and M. H. Bahi ( 2000) . The Methods of Scientific Research and Statistical Analysis in The sports, educational and psychological status, book publishing center, Egypt.

Al-Abbassi , A.F.(2015). Methods of scientific research and statistical Analyses in behavioral sciences, the first print, university of Mosul ,Iraq , :370 -464 .

Al-Abbassi, A. F., A. Z. al-Hafidh and R. M. Al- Chalabi,( 2010). The knowledge of the rural youth in the villages of / Terms / Ninawa governorate, in the area of agriculture and its relation with some summer vegetables, Journal of the Tikrit University of Agricultural Sciences, the Tikrit University, Faculty of Agriculture and Forestry, a Tikrit, Iraq,15(3).

Al-Ekaby,S.A and B.A.R,(2017).Supposed proposal for decentralized management of agricultural extension system In the provinces of central region of Iraq, The Iraq journal of Agricultural sciences -1284, 1294,5( 48):1285 .

Anonymous,(2009) . Study Report Training and Information Needs in the field of Agricultural Diversification Needs in the field of Agricultural Divarication and Comercialsation in St.lucia, European Union, Survey of St.Lucia's NonBanana Farmers ,Hamburg University of Applied sciences : 33 .

Al-Jarjari , d. N . (2011).Psychological support to pilot projects in the dissemination of knowledge and modern agricultural techniques - a case study of a project for supporting farmers potato spring session in Rabia Distract / Nineveh province, Iraqi Agriculture Research (magazine),16(1): 197-204.

AL-Talib , A.A.( 2007) . Assessment of knowledge level of tomato farmers and its relationship with some variable in zomar sub-district nineveh governorate journal of Al-rafidain agriculture ,35(4), (Abstract) .

Thallaj,A.A.and E.Y.Al-Najjar,(2013).Economic analisisto potato production efficiency in talkief region/nineveh governorate in spring reason2011,mesotopamia j.of agric.41(2):13

Khazraji, R. M. I. .( 2011). Cognitive planning needs for evaluators agricultural indicative planning in bodies and public corporations, the Iraqi agricultural science magazine, 41-42 (1) :70-81.

Mahmoud, H. Sh.(2008). Instructional knowledge needs for sun flower farmers in Diyala governorate, by oil statements techniques , Technical medical Institute, Baghdad

Rogers , E.M.( 2003) .A model of five stages in the Innovation -Decision process , diffusion of Innovation, fourth Edition : 13 .

Shafeeq,H.(2016).The Management Davison of Iraq :The full picture World Atlas ,Scientifically For Researches ,UNESCO,Dar -Makeekh For Science ,Baghdad :35.

Shams Al-Din S. A .( 2011). information theory, concepts and tips basic issues, Journal of knowledge, research and studies, Syria 450:10-23.

Tharwat, M.A. M. (2004). Modern entrance for statistics and prospects, Al obaikan library. 
Ziemianczyk , U . Etat.( 2014).Knowledge management in the process of building competitiveness and innovativeness of rural area ,Online Journal of Applied Knowledge Management ,2( 2):43. 